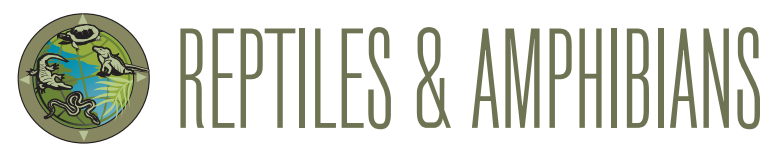

\title{
New Distribution and Elevational Records and Intraspecific Variation in the Assam Forest Frog, Hydrophylax leptoglossa (Cope 1868) (Anuran: Ranidae), in Mizoram, India
}

Lal Duhzuali, Lal Muansanga, Fanai Malsawmdawngliana, Vabeiryureilai Mathipi, Zothang Liana, and H.T. Lalremsanga

Developmental Biology and Herpetology Laboratory, Department of Zoology, Mizoram University, Aizawl, 796004, Mizoram, India (muanapunte16@gmail.com)

$\mathrm{T}$ he family Ranidae comprises a wide-ranging group of frogs, collectively distributed from southern South America to South Africa, Madagascar, and most of Australia, containing several genera and more than 600 species. The genus Hydrophylax consists of four currently recognized species of which the Assam Forest Frog (Hydrophylax leptoglossa) occurs in the northeastern Indian states of Assam, Tripura, Meghalaya, and Mizoram (Frost 2021). In Mizoram, the species has been reported previously from the Dampa Tiger Reserve in Mamit District (Pawar and Birand 2001; Decemson et al. 2021), and from Kolasib District (Lalremsanga et al. 2007).

We conducted visual and acoustic encounter surveys from six localities throughout Mizoram from February to July 2019 (Fig. 1), during which we collected eight male and four female H. leptoglossa. The identities of all collected frogs were verified by Jayaditya Purkayashtha. Specimens were catalogued in the Amphibian Section, Departmental Museum of Zoology, Mizoram University, Aizawl, Mizoram, India, as MZMU 782, 787-8 from Saihapui, Kolasib

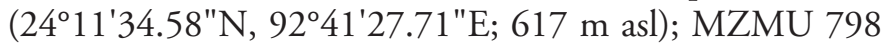
from Tuivamit, Aizawl (234' $49.47^{\prime \prime N}, 92^{\circ} 40^{\prime} 51.23^{\prime \prime E} ; 858$ $\mathrm{m}$ asl); MZMU 1123-4, 1129-30, 1764 from Thenzawl, Serchhip (2316'56.80"N, 9246'9.63"E; $764 \mathrm{~m}$ asl); MZMU 1773,1780 from the Pualreng Wildlife Sanctuary, Kolasib (24ํ'13'29.47"N, 9248'12.08"E; 593 m asl); MZMU 1799 from the Tokalo Wildlife Sanctuaru, Siaha $\left(22^{\circ} 03^{\prime} 48.59^{\prime \prime N}\right.$, $92^{\circ} 55^{\prime} 12.60 " \mathrm{E} ; 72 \mathrm{~m}$ asl); and MZMU 1818 from the Palak Wildlife Sanctuary, Saiha (22¹2'17.93"N, 9253'12.91"E; $277 \mathrm{~m}$ asl). These localities represent new records for the species in Mizoram and include a new elevational record. The range reported for $H$. leptoglossa by the IUCN SSC Amphibian Specialist Group (2016) was 15-700 m asl but the individual (MZMU 798) collected beside a highly disturbed pond at Tuivamit, Aizawl, was at an elevation of $858 \mathrm{~m}$ asl (Fig. 2).
We amplified the 16s rRNA gene using primers L02510 (Palumbi 1996) and H03063 (Rassmann 1997) and compared it to 15 sequences from related species obtained from the NCBI database. A Common Asian Toad (Duttaphrynus melanostictus) (MW165455) was used as an outgroup. We aligned the sequences using the MUSCLE algorithm in

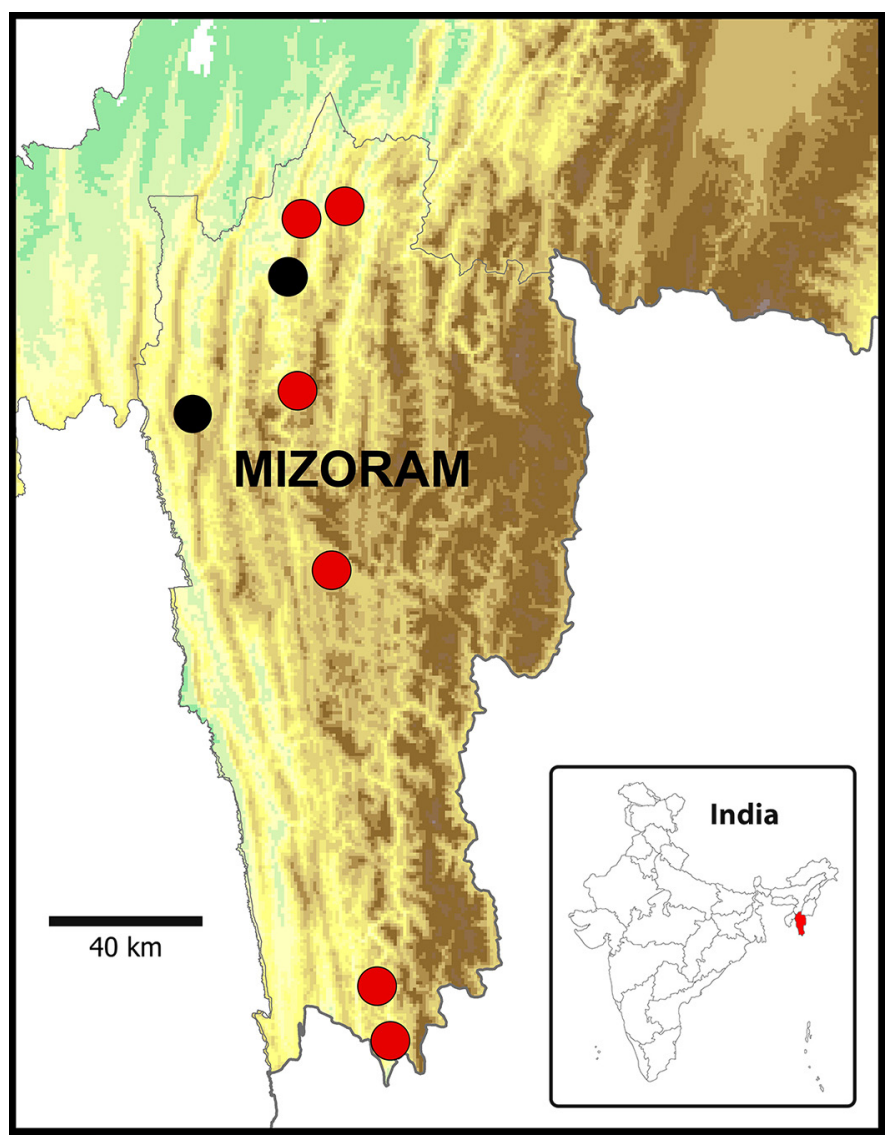

Fig 1. Map of Mizoram, India, showing sampling sites of Assam Forest Frogs (Hydrophylax leptoglossa). Previously reported localities are marked in black and the new localities in red. 

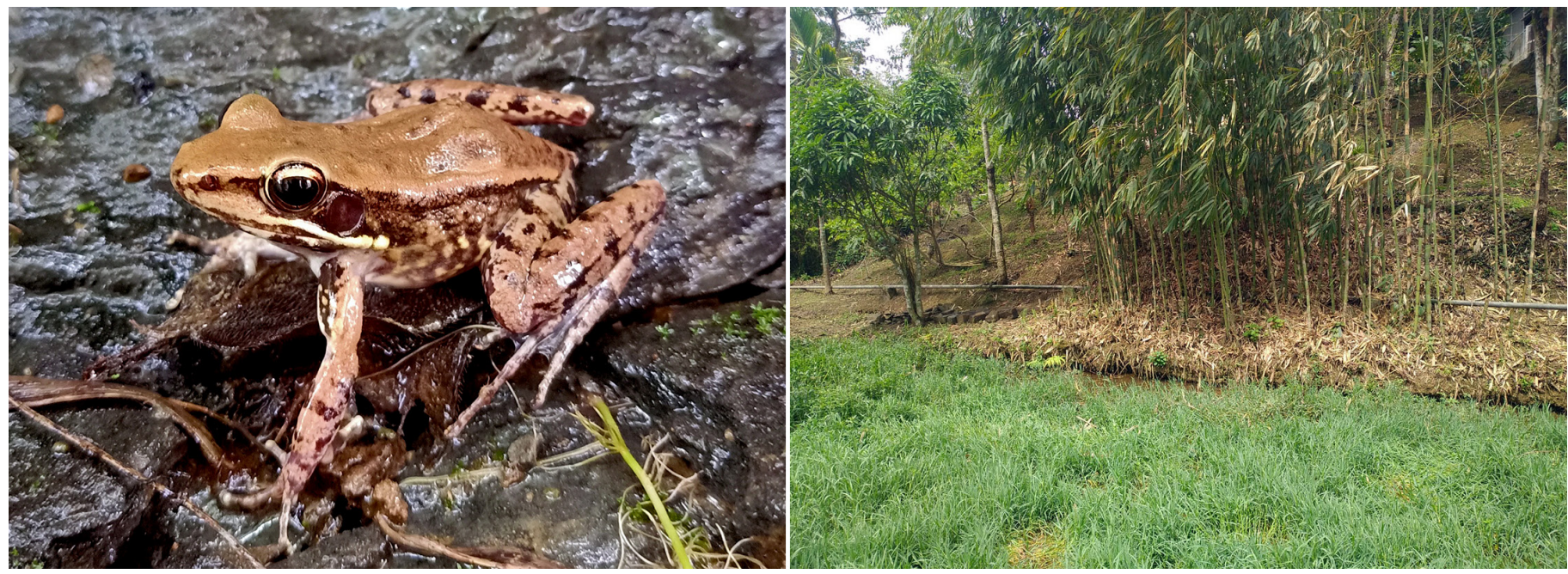

Fig. 2. An Assam Forest Frog (Hydrophylax leptoglossa) (left) collected at an elevation of $858 \mathrm{~m}$ asl from a damp microhabitat (right) in Tuivamit, Aizawl District, Mizoram, India. Photograph by H.T. Lalremsanga.

MEGA 7 (Kumar et al. 2016) and constructed a phylogenetic tree by MrBayes (v. 2.7) using the GTR $+\mathrm{I}+\mathrm{G}$ model (Huelsenbeck and Ronquist 2001) (Fig. 3). The estimated K2P genetic distance between Hydrophylax leptoglossa from the Pualreng Wildlife Sanctuary (PWS) (MS165466), the Palak National Wetland (PNW) (MW165470), both in Mizoram, and H. leptoglossa (KM069011) from Manipur in northeastern India (MW165466) (Biju et al. 2014) was zero. However, H. leptoglossa (MT790753) from the Dampa Tiger Reserve (DTR) in Mizoram differed by an unpaired genetic distance of $0.24 \%$ from the sample from the Pualreng Wildlife Sanctuary (MW165466).

\section{Acknowledgements}

We thank Mr. Liandawla (Principal Chief Conservator of Forests), Government of Mizoram, for issuing a permit (No. A.33011/2/99-CWLW/225) to collect herpetofauna in Mizoram; and the Defence Research Development Organisation (DRDO), Ministry of Defence (No. DFTM/07/3606/NESTC/ABR/M/P-01).

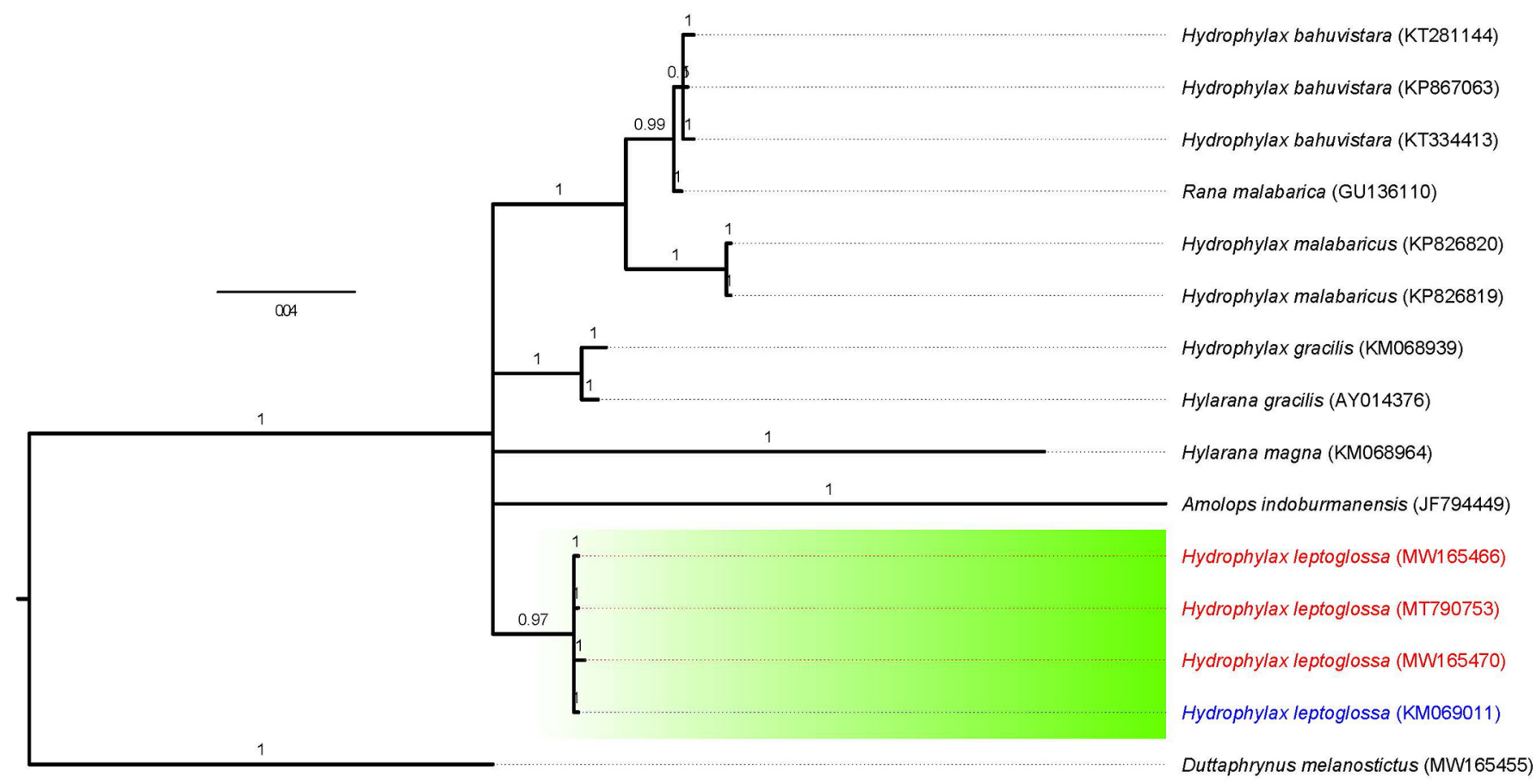

Fig. 3. Maximum-likelihood phylogram (16s rRNA) of Assam Forest Frogs (Hydrophylax leptoglossa) and related species. Numbers at nodes represent bootstrap support. The Common Asian Toad (Duttaphrynus melanostictus) (MW165455) was used as the outgroup. Red indicates frogs from this study and blue marks a conspecific from Manipur in northeastern India. 


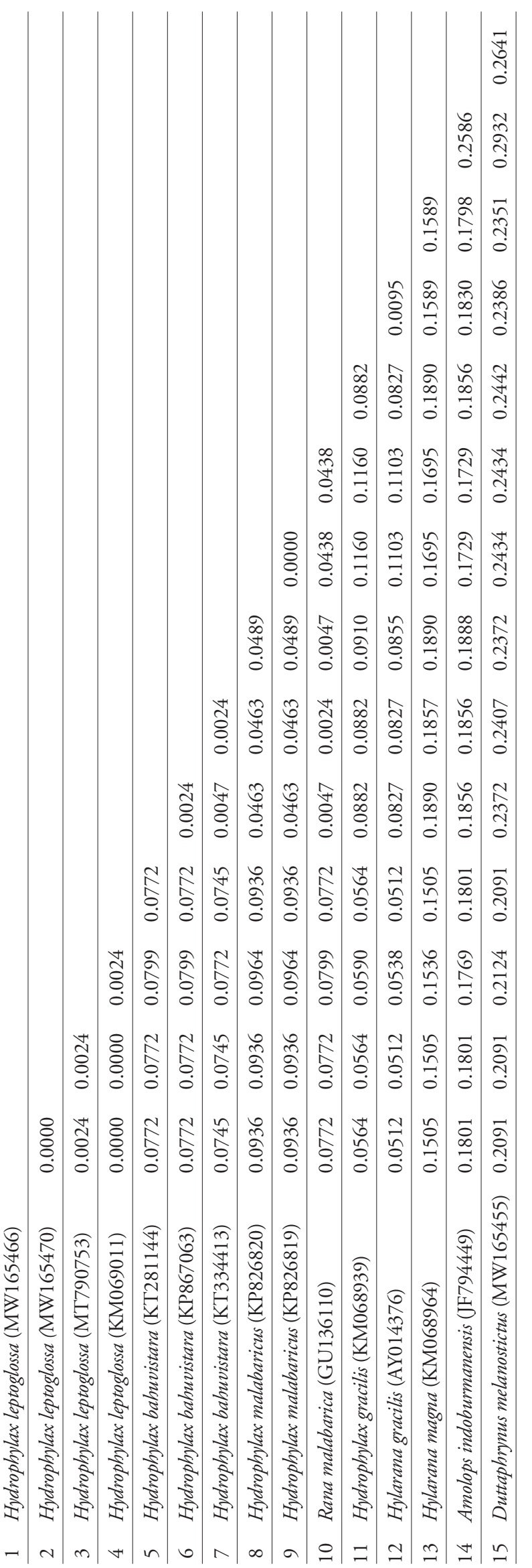

\section{Literature Cited}

Biju, S.D., S. Garg, S. Mahony, N. Wijayathilaka, G. Senevirathne, and M. Meegaskumbura. 2014. DNA barcoding, phylogeny and systematics of Golden-backed frogs (Hylarana, Ranidae) of the Western Ghats-Sri Lanka biodiversity hotspot, with the description of seven new species. Contributions to Zoology 83: 269-335. http://dx.doi.org/10.1163/18759866-08304004.

Decemson, H., S. Gouda, Lalbiakzuala, Lalmuansanga, G.Z. Hmar, M. Vabeiryureilai, and H.T. Lalremsanga. 2021. An annotated checklist of amphibians in and around Dampa Tiger Reserve, Mizoram, India. Journal of Threatened Taxa 13: 17918-17929. http://dx.doi.org/10.11609/jott.6319.13.3.17918-17929.

Frost, D.R. 2021. Amphibian Species of the World: An Online Reference. Version 6.1. American Museum of Natural History, New York, New York, USA. <https:// amphibiansoftheworld.amnh.org/index.php>. https://doi.org/10.5531/ db.vz.0001.

Huelsenbeck, J.P. and F. Ronquist. 2001. MRBAYES: Bayesian inference of phylogeny. Bioinformatics 17: 754-755. http://dx.doi.org/10.1093/bioinformatics/17.8.754.

IUCN SSC Amphibian Specialist Group. 2016. Hydrophylax leptoglossa. The IUCN Red List of Threatened Species 2016: e.T58642A64131614. http://dx.doi. org/10.2305/IUCN.UK.2016-3.RLTS.T58642A64131614.en.

Kumar, S., G. Stecher, and K. Tamura. 2016. MEGA7: Molecular evolutionary genetics analysis version 7.0 for bigger datasets. Molecular Biology and Evolution 33: 1870-1874. https://doi.org/10.1093/molbev/msw054.

Lalremsanga, H.T., S. Sailo, B. Kharbuli, and R.N.K. Hooroo. 2007. Record of Sylvirana leptoglossa (Cope, 1868) (Anura: Ranidae) from Kolasib district, Mizoram, northeastern India. Frog Leg. Newsletter of the Amphibian Network of South Asia and Amphibian Specialist Group - South Asia 13: 9-10.

Palumbi, S.R. 1996. Nucleic acids II: The polymerase chain reaction, pp. 205-247. In: D.M. Hillis, C. Moritz, and B.K. Mable (eds.), Molecular Systematics. 2nd edition. Sinauer Associates, Inc., Sunderland, Massachusetts, USA.

Pawar, S. and A. Birand. 2001. A survey of amphibians, reptiles, and birds in Northeast India. CERC Technical Report \#6. Centre for Ecological Research and Conservation, Mysore, India.

Rassmann, K. 1997. Evolutionary age of the Galápagos iguanas predates the age of the present Galápagos Islands. Molecular Phylogenetics and Evolution 7: 158-172. https://doi.org/10.1006/MPEV.1996.0386.
Table 1. The uncorrected K2p distances of Assam Forest Frogs (Hydrophylax leptoglossa) and related species based on partial $16 \mathrm{~S}$ rRNA gene sequences. 